TELLES, CC; FREITAS, LM; JUNQUEIRA, AMR; MENDONÇA, RS. 2019. Silicon application as an auxiliary method to control diamondback moth in cabbage plants. Horticultura Brasileira 37: 390-394. DOI - http://dx.doi.org/10.1590/S0102-053620190405

\title{
Silicon application as an auxiliary method to control diamondback moth in cabbage plants
}

\author{
Camila C Telles $^{1} \mathbb{D}$; Luciana $M$ de Freitas ${ }^{2} \mathbb{D}$; Ana Maria R Junqueira ${ }^{1} \mathbb{D}$; Renata S de Mendonça ${ }^{1} \mathbb{D}$
}

${ }^{1}$ Universidade de Brasília, Faculdade de Agronomia e Medicina Veterinária (FAV-UnB), Brasília-DF, Brasil; camilacembrolla@hotmail. com; anamaria@unb.br; renatamendonca@unb.br; ${ }^{2}$ Centro Universitário Icesp, Brasília-DF, Brasil; moraisluciana@yahoo.com.br

\begin{abstract}
Integrated pest management (IPM) strategies are among the factors promoting plant resistance to pests, and silicon application may increase this resistance. Thus, the aim of this research was to evaluate the control of diamondback moth (DBM), Plutella xylostella (Lepidoptera, Plutellidae) through foliar application of silicon in cabbage crops. The experiment was conducted in the vegetable producing area of Água Limpa Farm, Universidade de Brasília, Distrito Federal, Brasil. The experimental design was of randomized blocks with nine treatments and four replicates, totaling 36 plots. The applied treatments consisted of Agrosilicon ${ }^{\circledast}(10.5 \% \mathrm{Si})$ (T1), $\mathrm{Sifol}^{\circledR}(12 \% \mathrm{Si})$ (T2), deltamethrin $25 \mathrm{~g} \mathrm{~L}^{-1}$ (Decis ${ }^{\circledR} 25 \mathrm{EC}$ ) (T3), Bacillus thuringiensis, $33.60 \mathrm{~g} \mathrm{~L}^{-1}$ (Dipel ${ }^{\mathbb{B}}$ SC) (T4), Agrosilicon ${ }^{\circledR}+$ deltamethrin $25 \mathrm{~g} \mathrm{~L}^{-1}\left(\right.$ Decis $^{\circledR} 25$ EC) (T5), Agrosilicon ${ }^{\circledR}+$ Bacillus thuringiensis, $33.60 \mathrm{~g} \mathrm{~L}^{-1}$ (Dipel ${ }^{\circledR}$ SC) (T6), Sifol ${ }^{\circledR}+$ deltamethrin $^{8}$

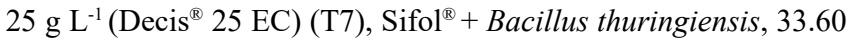
g L $^{-1}$ (Dipel $^{\circledR}$ SC) (T8) and control (T9). Agrosilicon ${ }^{\circledR}$ and Sifol ${ }^{\circledR}$ were applied weekly and the products deltamethrin and Bacillus thuringiensis were applied according to the damage level established for DBM in cabbage crops. Foliar application of silicon, alone or in combination with chemical and biological insecticides - T2, T7 and $\mathrm{T} 8$, were the best strategy to control DBM in cabbage crops, resulting in the lowest number of caterpillars per plant, lowest leaf damages and best aesthetic value of plants. Silicon foliar application can be considered as an auxiliary method of DBM management in cabbage crops, followed by the doses recommended by the manufacturers.
\end{abstract}

Keywords: Brassica oleracea var. capitata, Plutella xylostella, Bacillus thuringiensis, insecticides, mechanical resistance.

\section{RESUMO}

Aplicação de silício como método auxiliar no controle da traça das crucíferas na cultura do repolho

Entre as estratégias de Manejo Integrado de Pragas (MIP) estão os fatores que induzem a resistência da planta hospedeira. A adubação mineral com silício pode aumentar a resistência de plantas ao ataque de pragas. Este trabalho teve como objetivo avaliar o potencial da aplicação de silício no controle da traça-das-crucíferas (TDC), Plutella xylostella (Lepidoptera, Plutellidae), na cultura do repolho. $\mathrm{O}$ experimento foi conduzido na área de produção de hortaliças da Fazenda Água Limpa, Universidade de Brasília, Brasília-DF. O delineamento experimental foi em blocos ao acaso, com nove tratamentos e quatro repetições, totalizando 36 parcelas. Os tratamentos foram T1= aplicação foliar de $\operatorname{Agrosilício~}^{\circledR}(10,5 \% \mathrm{Si})$; $\mathrm{T} 2=$ aplicação foliar de Sifol ${ }^{\circledR}(12 \% \mathrm{Si}) ; \mathrm{T} 3=$ aplicação do inseticida deltametrina $25 \mathrm{~g} / \mathrm{L}$ (Decis $\left.{ }^{\circledR} 25 \mathrm{EC}\right) ; \mathrm{T} 4=$ aplicação do bioinseticida Bacillus thuringiensis 33,60 g/L (Dipel ${ }^{\mathbb{S}} \mathrm{SC}$ ); T5= Agrosilício $^{\circledR}$ $(10,5 \% \mathrm{Si})+$ deltametrina $25 \mathrm{~g} / \mathrm{L}\left(\right.$ Decis $\left.^{\circledR} 25 \mathrm{EC}\right) ; \mathrm{T} 6=$ Agrosilício $^{\circledR}$ $(10,5 \% \mathrm{Si})+$ Bacillus thuringiensis $33,60 \mathrm{~g} / \mathrm{L}$ (Dipel $\left.{ }^{\circledR} \mathrm{SC}\right) ; \mathrm{T} 7=\mathrm{Sifol}^{\circledR}$ $(12 \% \mathrm{Si})+$ deltametrina $25 \mathrm{~g} / \mathrm{L}\left(\right.$ Decis $\left.^{\circledR} 25 \mathrm{EC}\right) ; \mathrm{T} 8=\mathrm{Sifol}^{\circledR}(12 \%$ $\mathrm{Si})+$ Bacillus thuringiensis $33,60 \mathrm{~g} / \mathrm{L}\left(\right.$ Dipel $\left.^{\circledR} \mathrm{SC}\right)$ e $\mathrm{T} 9=$ tratamento controle. As aplicações de Agrosilicio ${ }^{\circledR}$ e Sifol ${ }^{\circledR}$ foram realizadas semanalmente via foliar. As aplicações dos produtos deltametrina e Bacillus thuringiensis foram realizadas quando se atingiu o nível de controle definido para a TDC na cultura do repolho. A aplicação de silício via foliar, isolada ou associada aos inseticidas químicos e biológicos, T2, T7 e T8, resultou na melhor estratégia de controle da TDC na cultura do repolho, com menor número de lagartas por planta, menor número de perfurações nas folhas e melhor avaliação estética das plantas de repolho. $\mathrm{O}$ uso do silício via foliar apresenta potencial como método auxiliar de manejo da TDC em repolho, seguindo-se as doses recomendadas pelos fabricantes.

Palavras-chave: Brassica oleracea var. capitata, Plutella xylostella, Bacillus thuringiensis, inseticidas, resistência mecânica.

\section{Received on March 21, 2019; accepted on September 25, 2019}

$\mathrm{S}$ ilicon is the second most abundant element in the earth's crust. It is absorbed by plant roots as soluble silicic acid $\left[\mathrm{Si}(\mathrm{OH})_{4}\right]$ and converted into insoluble silica in cell walls, intercellular spaces and subcuticular layers of leaves (Ma et al., 2011). The activation of plant protection mechanisms, observed with silicon applications (Gozzo \& Faoro, 2013), denotes its potential in disease control. Moreover, the indirect action of silicon on the third trophic level increases the attraction of natural enemies to herbivorous insects (Reynolds et al., 2009).

Although silicon is not considered an essential element for plant, silicon- 
deprived plants are often structurally weaker than silicon-replete plants, i.g., abnormal in growth, development, viability, and reproduction, more susceptible to abiotic stresses, and easier prey to disease organisms and to phytophagous insects (Epstein, 1999). The increased yield, with silicon foliar application, was observed in corn (Sousa et al., 2010), soybean (Teodoro et al., 2015) and in the production of eucalyptus seedlings (Navas et al., 2016).

Silicon applications induce plant resistance to insect pests by forming mechanical barriers on the outer cell wall of plants (Goussain et al., 2002; Costa \& Moraes, 2006; Freitas et al., 2014), increasing the synthesis of phenolic compounds and lignin (Currie \& Perry, 2007) and activating endogenous chemical defenses of attacked plants (Epstein, 2009; Kvedaras et al., 2009). The use of silicon in integrated pest management (IPM) have been reported with promising results to control several insect pests in crops of economic importance, such as Spodoptera frugiperda (Lepidoptera: Noctuidae) in maize (Goussain et al., 2002), Eldana saccharina and Diatraea saccharalis (Fabricius) (Lepidoptera: Crambidae) in sugarcane (Vilela et al., 2014), Schizaphis graminum (Hemiptera: Aphididae) in sorghum (Costa \& Moraes, 2006) and wheat (Costa et al., 2007), Cinara atlantica (Hemiptera: Aphididae) in pinus (Camargo et al., 2008), Diabrotica speciosa (Coleoptera: Chrysomelidae) in potato (Assis et al., 2013), Bemisia tabaci (Hemiptera: Aleyrodidae) in soybean (Ferreira et al., 2011), Tuta absoluta (Lepidoptera: Gelechiidae) in tomato (Santos et al., 2012), and Chlosynela ciniasaundersii (Lepidoptera: Nymphalidae) in sunflower (Assis et al., 2013) crops. Laboratory experiments with DBM on cabbage confirmed the effect of silicon on its feeding preference, mortality and on the anatomy of their mandibles, indicating its use as a complementary tool in IPM (Freitas et al., 2012).

The diamondback moth (DBM), Plutella xylostella (Lepidoptera: Plutellidae) is the main pest of cabbage (Brassica oleracea var. capitata) and frequently infests cabbage crops causing serious damage (Freitas et al., 2012). DBM caterpillars feed on leaves leaving them with a perforated appearance (Luz et al., 2002). The control of this pest is performed through intense use of insecticides, which has caused selection of resistant populations (Zhuang et al., 2011), environmental impacts and risks to human health (Ribas \& Matsumura, 2009). Therefore, studies on IPM practices to control this insect have been conducted (Monnerat et al., 2000; Neri et al., 2005; Gomes et al., 2008; Freitas et al., 2012).

In this context, the aim of this work was to evaluate the control of $P$. xylostella through foliar fertilization with silicon in cabbage crops.

\section{MATERIAL AND METHODS}

The experiment was conducted in the vegetable producing area of Água Limpa Farm of the Universidade de Brasilia, Distrito Federal, Brasil (15 $57^{\prime} 10^{\prime \prime} \mathrm{S}$, 47 57'13"W, 1,100 m altitude), from August to November 2013. According to Köppen classification, the climate of the region is Aw tropical of savannah, with dry winters and rainy summers. The soil of the area is classified as Oxisol (Red-Yellow Latosol, SiBCS) of clayey texture.

Cabbage seedlings were produced in 128-cell polypropylene trays under protected environment using commercial substrate (Bioplant Agrícola Ltda). Seedlings were transplanted with four permanent leaves. The planting area $\left(322 \mathrm{~m}^{2}\right)$ was divided into $8.96 \mathrm{~m}^{2}$ plots $(2.8 \times 3.2 \mathrm{~m})$. Plots consisted of four cabbage (cultivar Kenzan) plant rows, $0.4 \mathrm{~m}$ between plants and $0.8 \mathrm{~m}$ between rows, totaling 28 plants per plot. The evaluation area of each plot consisted of the two central rows (ten plants), from which five plants were evaluated.

The experimental design was of randomized blocks with nine treatments and four replicates, totaling 36 plots. Treatments consisted of weekly foliar fertilization with Agrosilicon ${ }^{\circledR}(10.5 \%$ Si) (T1), weekly foliar fertilization with $\mathrm{Sifol}^{\circledR}(12 \% \mathrm{Si})$ (T2), chemical insecticide application with deltamethrin
$25 \mathrm{~g} \mathrm{~L}^{-1}$ (Decis ${ }^{\circledR} 25 \mathrm{EC}$ ) (T3), biological insecticide application with Bacillus thuringiensis, $33.60 \mathrm{~g} \mathrm{~L}^{-1}\left(\operatorname{Dipel}^{\circledR} \mathrm{SC}\right)$

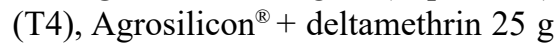
$\mathrm{L}^{-1}$ (Decis 25 EC) (T5), Agrosilicon ${ }^{\circledR}+$ Bacillus thuringiensis, $33.60 \mathrm{~g} \mathrm{~L}^{-1}\left(\right.$ Dipel $^{\circledR}$

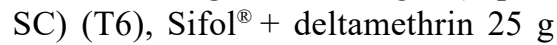
$\mathrm{L}^{-1}\left(\right.$ Decis $\left.^{\circledR} 25 \mathrm{EC}\right)(\mathrm{T} 7)$, Sifol $^{\circledR}+$ Bacillus thuringiensis, $33.60 \mathrm{~g} \mathrm{~L}^{-1}$ (Dipel ${ }^{\circledR} \mathrm{SC}$ ) (T8) and a control with water application (T9).

The eight foliar applications with silicon $\left(\right.$ Agrosilicon $^{\circledR}$ and Sifol ${ }^{\circledR}$ ) were carried out during the cabbage cycle and the first insecticide (deltamethrin) and bio-insecticide (Bacillus thuringiensis) applications were performed in the morning, using a 20 L backpack sprayer with conical nozzle, from 30 days after the seedling transplanting until the cabbage heads were completely formed.

Treatments with deltamethrin and Bacillus thuringiensis, alone or in combination with silicon, were performed according to the manufacturer recommendations, whenever the economic damage level for DBM, six perfurations in the four central leaves (Castelo Branco et al., 1996), was reached. Seven applications were required during the crop cycle.

The number of DBM caterpillars and injuries caused by DBM were weekly evaluated from one week after the first foliar application of silicon until the end of the cycle. The number of perfurations and caterpillars in the four central leaves of the cabbage plant was counted, according to Castelo Branco et al. (1996). Cabbage heads were harvested and their aesthetic appearance score was evaluated according to the scale of grades suggested by Castelo Branco et al. (1996) and Villas Bôas et al. (2004), based on leaf damage caused by DBM, e.g., $1=$ leaves scraped or undamaged, $2=$ leaves with small perfurations, little damaged, $3=$ leaves with large perfurations, damaged, 4= leaves totally damaged, not marketable. The lowest the score, the fewer damages caused by DBM. The cabbage marketable production was also evaluated, considering their fresh weight and head circumference.

Data collected by three independent subjects were submitted to analysis of 
variance and means were compared by the Scott-Knott test at the 5\% of probability.

\section{RESULTS AND DISCUSSION}

\section{Number of DBM caterpillars}

The lowest number of caterpillars per cabbage plant was found in treatments containing Sifol ${ }^{\circledR}$ (T2, T7 and T8) (Table 1). The mean number of caterpillars in these treatments was significantly lower than those in the treatments with the products deltamethrin (T3) and Bacillus thuringiensis (T4), applied alone or in combination with Agrosilicon ${ }^{\circledR}$ (T5 and T6).

The control efficiency of the products deltamethrin and Bacillus thuringiensis, applied in combination with Sifol ${ }^{\circledR}$ (T7 and T8), increased in 76 and $82.5 \%$, respectively, compared with their applications alone (T3 and T4). These results denote that the good performance of treatments $\mathrm{T} 7$ and $\mathrm{T} 8$ is due to the silicon, since there were no significant differences between treatments T2, T7 and T8. The largest caterpillar infestations were observed in treatments with Agrosilicon ${ }^{\circledR}$ (T1) and control (T9).

The number of caterpillars in cabbage plants treated by Agrosilicon ${ }^{\circledR}$ (T1) did not differ from the control (T9) at 37, 58, 65 and 79 days after transplant (DAT). Sifol ${ }^{\circledR}$ treatments in different evaluation periods, alone or in combination, had lower average number of caterpillars, except Sifol ${ }^{\circledR}$ + deltamethrin (T7), at 72 DAT, that showed an average number higher than other treatments performed with $\mathrm{Sifol}^{\circledR}$.

The significant results of silicon treatments with $\mathrm{Sifol}^{\circledR}$ in the field confirm laboratorial studies carried out with DBM caterpillars by Freitas et al. (2012), in which silicon application (12 $\mathrm{kg} \mathrm{ha}^{-1}$ ) affected feeding of caterpillars causing their death. Goussain et al. (2002) found significant effect of silicon fertilization in maize on mortality of second instar caterpillars of $S$. frugiperda fed on leaves treated with this mineral, with twice the mortality occurred in the control (6.8 and 3.3\%, respectively). Neri et al. (2005) found positive effect of soil and foliar applications of silicon and their interaction with the insecticide lufenuron to control $S$. frugiperda in maize plants, allowing them to reduce $50 \%$ of the physiological insecticide rate. Gomes et al. (2008) evaluated the control of Myzus persicae (Hemiptera: Aphididae) in potato with applications of silicon and imidacloprid and recommended silicon fertilization in IPM in potato. The use of silicon to induce plant resistance to pests was discussed by Camargo et al. (2008), Epstein (2009), Reynolds et al. (2009) and Kvedaras et al. (2009). In the present work, Agrosilicon ${ }^{\circledR}$ had lower efficiency than Sifol ${ }^{\circledR}$ to control DBM.

\section{Injury caused by DBM}

The number of perfurations caused by DBM caterpillars on cabbage leaves reduced with the treatments applied (Table 2).

The lowest mean number of perfurations was found in plants treated with Sifol ${ }^{\circledR}$ (T2, T7 and T8), which did not differ from the means found in plants treated with Agrosilicon ${ }^{\circledR}+$ Bacillus thuringiensis (T6) (Table 2).

No additional applications of deltamethrin and Bacillus thuringiensis were required by plants in $\mathrm{T} 7\left(\mathrm{Sifol}^{\circledR}+\right.$ deltamethrin) and T8 (Sifol ${ }^{\circledR}+$ Bacillus thuringiensis). Eight foliar fertilizations with Sifol ${ }^{\circledR}$ controlled the DBM. The damage level adopted for DBM, six perfurations in the four central leaves (Castelo Branco et al., 1996), was not reached in the treatments $\mathrm{T} 2, \mathrm{~T} 7$ and T8. According to Freitas et al. (2012), foliar fertilization with silicon affect the feeding preference and anatomy of mandibles of DBM caterpillars, increasing their mortality rates and decreasing the number of perforations in cabbage leaves. Applications of Sifol ${ }^{\circledR}$ with insecticide (T7 and T8), considering a single application, increased the control efficiency, reducing the number of perforations in $71.9 \%$ and $50 \%$, respectively, compared with the insecticides deltamethrin (T3= with four applications) and Bacillus thuringiensis (T4= with two applications) applied alone.

Injury caused by DBM on the cabbage plants treated with Agrosilicon ${ }^{\circledR}$ (T1) was similar to that observed

Table 1. Number of Plutella xylostella caterpillars on cabbage plants (Brassica oleraceae var. capitata cv. Kenzan), with single and combined applications of silicon and insecticides during the crop cycle. Brasília, UnB, 2013.

\begin{tabular}{|c|c|c|c|c|c|c|c|c|c|}
\hline \multirow{2}{*}{\multicolumn{2}{|c|}{ Treatment }} & \multicolumn{7}{|c|}{ Days after transplanting } & \multirow{3}{*}{$\begin{array}{c}\text { Mean } \\
1.0 \mathrm{c}\end{array}$} \\
\hline & & \multirow{2}{*}{$\begin{array}{c}37 \\
1.4 \mathrm{~b}\end{array}$} & \multirow{2}{*}{$\begin{array}{l}44 \\
0.2 \mathrm{a}\end{array}$} & \multirow{2}{*}{\begin{tabular}{|l|}
$\mathbf{5 1}$ \\
$1.4 \mathrm{~b}$
\end{tabular}} & \multirow{2}{*}{$\begin{array}{c}\mathbf{5 8} \\
1.0 \mathrm{~b}\end{array}$} & \multirow{2}{*}{$\begin{array}{c}\mathbf{6 5} \\
1.0 \mathrm{~b}\end{array}$} & \multirow{2}{*}{$\begin{array}{c}72 \\
1.0 \mathrm{~b}\end{array}$} & \multirow{2}{*}{$\frac{79}{1.2 b}$} & \\
\hline $\mathrm{T} 1$ & Agrosilicon & & & & & & & & \\
\hline $\mathrm{T} 2$ & Sifol & $0.2 \mathrm{a}$ & $0.0 \mathrm{a}$ & $0.0 \mathrm{a}$ & $0.2 \mathrm{a}$ & $1.0 \mathrm{~b}$ & $0.2 \mathrm{a}$ & $0.0 \mathrm{a}$ & $0.2 \mathrm{a}$ \\
\hline $\mathrm{T} 3$ & Deltamethrin & $1.8 \mathrm{~b}$ & $1.4 \mathrm{~b}$ & $1.0 \mathrm{~b}$ & $0.0 \mathrm{a}$ & $0.8 \mathrm{~b}$ & $0.0 \mathrm{a}$ & $0.0 \mathrm{a}$ & $0.7 \mathrm{~b}$ \\
\hline $\mathrm{T} 4$ & Bacillus thuringiensis & $0.6 \mathrm{a}$ & $1.0 \mathrm{~b}$ & $1.0 \mathrm{~b}$ & $0.0 \mathrm{a}$ & $1.0 \mathrm{~b}$ & $0.8 \mathrm{~b}$ & $0.0 \mathrm{a}$ & $0.6 \mathrm{~b}$ \\
\hline T5 & Agrosilicon + deltamethrin & $1.2 \mathrm{~b}$ & $1.0 \mathrm{~b}$ & $1.0 \mathrm{~b}$ & $0.0 \mathrm{a}$ & $0.2 \mathrm{a}$ & $1.0 \mathrm{~b}$ & $0.0 \mathrm{a}$ & $0.6 \mathrm{~b}$ \\
\hline T6 & Agrosilicon $+B$. thuringiensis & $0.6 \mathrm{a}$ & $0.4 \mathrm{a}$ & $1.2 \mathrm{~b}$ & $0.0 \mathrm{a}$ & $0.4 \mathrm{a}$ & $1.4 \mathrm{~b}$ & $0.0 \mathrm{a}$ & $0.6 \mathrm{~b}$ \\
\hline $\mathrm{T} 7$ & Sifol + deltamethrin & $0.2 \mathrm{a}$ & $0.0 \mathrm{a}$ & $0.0 \mathrm{a}$ & $0.0 \mathrm{a}$ & $0.0 \mathrm{a}$ & $1.0 \mathrm{~b}$ & $0.0 \mathrm{a}$ & $0.2 \mathrm{a}$ \\
\hline & Sifol $+B$. thuringiensis & $0.4 \mathrm{a}$ & $0.0 \mathrm{a}$ & $0.0 \mathrm{a}$ & $0.0 \mathrm{a}$ & $0.0 \mathrm{a}$ & $0.4 \mathrm{a}$ & $0.0 \mathrm{a}$ & $0.1 \mathrm{a}$ \\
\hline & Control & $1.2 \mathrm{~b}$ & $1.6 \mathrm{~b}$ & $2.6 \mathrm{c}$ & $1.2 \mathrm{~b}$ & $0.6 \mathrm{~b}$ & $0.4 \mathrm{a}$ & $0.0 \mathrm{a}$ & $1.1 \mathrm{c}$ \\
\hline
\end{tabular}

Means followed by same letters in the columns do not differ, Scott-Knott test at $5 \%$. 
Table 2. Number of perfurations caused by Plutella xylostella caterpillars on cabbage plants (Brassica oleraceae var. capitata cv. Kenzan), with singly and combined applications of silicon and insecticides. Brasília, UnB, 2013.

\begin{tabular}{|c|c|c|c|c|c|c|c|c|c|}
\hline \multirow{2}{*}{\multicolumn{2}{|c|}{ Treatment }} & \multicolumn{7}{|c|}{ Days after transplanting } & \multirow{3}{*}{$\frac{\text { Mean }}{7.4 \mathrm{c}}$} \\
\hline & & \multirow{2}{*}{$\begin{array}{c}\frac{37}{6.4 b} \\
\end{array}$} & \multirow{2}{*}{$\frac{44}{7.0 \mathrm{~b}}$} & \multirow{2}{*}{$\frac{51}{6.2 \mathrm{~b}}$} & \multirow{2}{*}{$\begin{array}{c}\mathbf{5 8} \\
10.0 \mathrm{~b}\end{array}$} & \multirow{2}{*}{$\begin{array}{c}\mathbf{6 5} \\
10.8 \mathrm{~b}\end{array}$} & \multirow{2}{*}{$\begin{array}{c}72 \\
6.2 \mathrm{~b}\end{array}$} & \multirow{2}{*}{$\begin{array}{l}79 \\
5.4 b\end{array}$} & \\
\hline $\mathrm{T} 1$ & Agrosilicon & & & & & & & & \\
\hline $\mathrm{T} 2$ & Sifol & $1.2 \mathrm{a}$ & $2.8 \mathrm{a}$ & $2.6 \mathrm{a}$ & $3.2 \mathrm{a}$ & $3.0 \mathrm{a}$ & $1.0 \mathrm{a}$ & $3.6 \mathrm{a}$ & $2.5 \mathrm{a}$ \\
\hline $\mathrm{T} 3$ & Deltamethrin & $8.6 \mathrm{~b}$ & $8.8 \mathrm{~b}$ & $6.0 \mathrm{~b}$ & $4.6 \mathrm{a}$ & $4.0 \mathrm{a}$ & $4.4 \mathrm{~b}$ & $2.0 \mathrm{a}$ & $5.5 \mathrm{~b}$ \\
\hline $\mathrm{T} 4$ & Bacillus thuringiensis & $4.4 \mathrm{a}$ & $4.0 \mathrm{a}$ & $5.4 \mathrm{~b}$ & $4.7 \mathrm{a}$ & $3.2 \mathrm{a}$ & $6.6 \mathrm{~b}$ & $2.2 \mathrm{a}$ & $4.4 \mathrm{~b}$ \\
\hline $\mathrm{T} 5$ & Agrosilicon + deltamethrin & $7.2 \mathrm{~b}$ & $7.4 \mathrm{~b}$ & $4.8 \mathrm{~b}$ & $4.0 \mathrm{a}$ & $3.6 \mathrm{a}$ & $3.6 \mathrm{a}$ & $1.2 \mathrm{a}$ & $4.5 \mathrm{~b}$ \\
\hline $\mathrm{T} 6$ & Agrosilicon $+B$. thuringiensis & $3.6 \mathrm{a}$ & $3.4 \mathrm{a}$ & $4.2 \mathrm{~b}$ & $3.6 \mathrm{a}$ & $2.4 \mathrm{a}$ & $5.2 \mathrm{~b}$ & $1.4 \mathrm{a}$ & $3.4 \mathrm{a}$ \\
\hline $\mathrm{T} 7$ & Sifol + deltamethrin & $1.6 \mathrm{a}$ & $2.2 \mathrm{a}$ & $0.2 \mathrm{a}$ & $2.6 \mathrm{a}$ & $1.6 \mathrm{a}$ & $1.6 \mathrm{a}$ & $1.0 \mathrm{a}$ & $1.5 \mathrm{a}$ \\
\hline $\mathrm{T} 8$ & Sifol + B. thuringiensis & $2.2 \mathrm{a}$ & $2.0 \mathrm{a}$ & $1.0 \mathrm{a}$ & $3.4 \mathrm{a}$ & $1.3 \mathrm{a}$ & $2.0 \mathrm{a}$ & $3.4 \mathrm{a}$ & $2.2 \mathrm{a}$ \\
\hline T9 & Control & $9.6 \mathrm{~b}$ & $10.2 \mathrm{~b}$ & $16.2 \mathrm{c}$ & $12.6 \mathrm{~b}$ & $8.4 \mathrm{~b}$ & $8.0 \mathrm{~b}$ & $6.4 \mathrm{~b}$ & $10.2 \mathrm{~d}$ \\
\hline
\end{tabular}

Means followed by same letters in the columns do not differ, Scott-Knott test at $5 \%$.

Table 3. Average head weight, circumference and Plutella xylostella (DBM) aesthetic score for cabbage plants (Brassica oleracea var. capitata cv. Kenzan), with single and combined applications of silicon and insecticides during the crop cycle. Brasília, UnB, 2013.

\begin{tabular}{lccc}
\hline \multirow{2}{*}{ Treatment } & $\begin{array}{c}\text { Average head Circumference } \\
\text { weight (g) }\end{array}$ & $\begin{array}{c}\text { Aesthetic } \\
\text { (cm) }\end{array}$ & $\begin{array}{l}\text { score (1 to 4) } \\
\text { T1 Agrosilicon }\end{array}$ \\
$713.0 \mathrm{a}$ & $45.9 \mathrm{a}$ & $2.2 \mathrm{c}$ \\
T2 Sifol & $722.8 \mathrm{a}$ & $47.1 \mathrm{a}$ & $1.0 \mathrm{a}$ \\
T3 Deltamethrin & $603.2 \mathrm{a}$ & $44.1 \mathrm{a}$ & $2.6 \mathrm{c}$ \\
T4 Bacillus thuringiensis & $725.0 \mathrm{a}$ & $46.7 \mathrm{a}$ & $1.8 \mathrm{~b}$ \\
T5 Agrosilicon + deltamethrin & $643.4 \mathrm{a}$ & $45.1 \mathrm{a}$ & $3.2 \mathrm{~d}$ \\
T6 Agrosilicon + B. thuringiensis & $715.4 \mathrm{a}$ & $45.2 \mathrm{a}$ & $2.2 \mathrm{c}$ \\
T7 Sifol + deltamethrin & $675.2 \mathrm{a}$ & $43.0 \mathrm{a}$ & $1.0 \mathrm{a}$ \\
T8 Sifol + B. thuringiensis & $1041.6 \mathrm{~b}$ & $53.1 \mathrm{a}$ & $1.0 \mathrm{a}$ \\
T9 Control & $602.0 \mathrm{a}$ & $43.4 \mathrm{a}$ & $3.6 \mathrm{~d}$ \\
\hline
\end{tabular}

Scores given according to the scale suggested by Castelo Branco et al. (1996) (1= leaves scraped or undamaged, $2=$ leaves with small perfurations, little damaged, $3=$ leaves with large perfurations, damaged, $4=$ plants with leaves totally damaged, not marketable). The lowest the score, the fewer damages caused by DBM.

in the control (T9) during different evaluation periods, except at 51 DAT. Treatments composed by $\mathrm{Sifol}^{\circledR}$, alone or in combination, showed lower mean number of perfurations caused by $P$. xylostella in all evaluation dates.

Although Agrosilicon ${ }^{\circledR}$ were not as effective as Sifol ${ }^{\circledR}$, the number of leaf perforations was significantly lower in plants treated with Agrosilicon ${ }^{\circledR}+$ Bacillus thuringiensis (T6); a single application of Agrosilicon ${ }^{\circledR}+$ Bacillus thuringiensis was sufficient to maintain the DBM below the damage level throughout the crop cycle. According to Bortoli et al. (2012), some biological characteristics of $P$. xylostella changed tool to control DBM.

Production and agronomic characteristics of plants

The cabbage head weight from plants treated with Sifol $^{\circledR}+$ Bacillus thuringiensis (1041.6 g) was significantly higher than those observed in other treatments. Cabbage crop yield is variable, usually higher than 50.000 $\mathrm{kg} \mathrm{ha}^{-1}$, with head weights of 1.5 to 2.0 $\mathrm{kg}$, according to market preferences (Filgueira, 2008). The cabbage head circumference was not significantly affected by treatments. The lowest score of DBM damages, i.e., best aesthetic aspect, were found in plants treated with $\mathrm{Sifol}^{\circledR}$, and the heads with highest DBM grades, i.e., worse aesthetic aspect, were found in treatments control and T5 (Table 3).

Plants treated with $\mathrm{Sifol}^{\circledR}$, alone or in combination with deltamethrin or Bacillus thuringiensis, had lower number of $P$. xylostella caterpillars, fewer leaf perforations and cabbage heads with better commercial value. The mean weight of cabbage heads was significantly higher in the treatment with Sifol $^{\mathbb{B}}+$ Bacillus thuringiensis (T8). The effect of treatments with Agrosilicon ${ }^{\circledR}$ to control DBM was lower than that with Sifol ${ }^{\circledR}$. This result can be due to the difference in silicon concentrations of these two sources (Agrosilicon ${ }^{\circledR}$ 10,5\% and $\left.\mathrm{Sifol}^{\circledR} 12 \%\right)$. Fertilization with $\mathrm{Sifol}^{\mathbb{Q}}$, alone or combined with chemical or biological insecticides, was the best strategy to control DBM, reducing its 
infestation, plant damage and number of insecticide applications, since the damage level was not reached within these treatments.

The results denote the importance of researches aiming to precise recommend silicon alone or in combined application with chemical and biological insecticides to control and manage P. xylostella. The possibility of reducing the number of insecticide applications or using lower rates than those recommended, with positive effects on yield and production costs, are highly required in pest management systems. Thus, foliar application of silicon has significant potential to control DBM in cabbage crops.

\section{ACKNOWLEDGEMENTS}

The authors are grateful to the Ministry of Education (FNDE National Fund for the Development of Education), for the scholarships granted to the first and third authors; to CAPES for the doctoral fellowship granted to the second author and the National Program of Post-Doctoral/ PNPD fellowship granted to the fourth author. The authors are also grateful to FAV-UnB and Fazenda Água LimpaUnB, for the logistical support.

\section{REFERENCES}

ASSIS, FA; MORAES, JC; AUAD, AM; COELHO, M. 2013. The effects of foliar spray application of silicon on plant damage levels and components of larval biology of the pest butterfly Chlosynela ciniasaundersii (Nymphalidae). International Journal of Pest Management 59: 128-134.

BORTOLI, SA; VACARI, AM; MAGALHAES, GO; DIBELLI, W; BORTOLI, CP;ALVES, MP. 2012. Subdosagens de Bacillus thuringiensis em Plutella xylostella (Lepidoptera: Plutellidae) e Trichogramma pretiosum (Hymenoptera: Trichogrammatidae). Revista Caatinga 25: 50-57.

CAMARGO, JMM; MORAES, JC; OLIVEIRA, EB; PENTEADO, SRC; CARVALHO, RCZ. 2008. Efeito da aplicação do silício em plantas de Pinus taeda L. sobre a biologia e morfologia de Cinara atlantica (Wilson) (Hemiptera: Aphididae). Ciência e Agrotecnologia 32:
1767-1774.

CASTELO BRANCO, M; VILLAS BÔAS, GL; FRANÇA, FH. 1996. Nível de dano de traça-das-crucíferas em repolho. Horticultura Brasileira 4: 154-157.

COSTA, RR; MORAES, JC. 2006. Efeitos do ácido silícico e do acibenzolar-S-methyl sobre Schizaphis graminum (Rondani) (Hemiptera: Aphididae) em plantas de trigo. Neotropical Entomology 5: 834-839.

COSTA, RR; MORAES, JC; ANTUNES, CS. 2007. Resistência induzida ao pulgão Schizaphis graminum (Rondani, 1852) (Hemiptera: Aphididae) por silicone e acibenzolar S Methil. Ciência e Agrotecnologia 31: 393-397.

CURRIE, HA; PERRY, CC. 2007. Silica in plants: biological, biochemical and chemical studies. Annals of Botany 100: 1383-1389.

EPSTEIN, E. 1999. Silicon. Annual Review of Plant Physiology and Plant Molecular Biology, 50: 641-664.

EPSTEIN, E. 2009. Silicon: manifold roles in plants. Annals of Applied Biology 155: 115116.

FERREIRA, RS; MORAES, JC; ANTUNES, CS. 2011. Silicon influence on resistance induced on against Bemisia tabaci biotype B (Genn.) (Hemiptera: Aleyrodidae) and on vegetal development in two soybean cultivars. Neotropical Entomology 40: 495-500.

FILGUEIRA, FAR. 2008. Novo manual de olericultura: agrotecnologia moderna na produção e comercialização de hortaliças. Viçosa: UFV. 421p.

FREITAS, LM; JUNQUEIRA, AMR; MICHEREFF FILHO, M. 2012. Potencial do uso do silício no manejo integrado da traçadas-crucíferas, Plutella xylostella, em plantas de repolho. Revista Caatinga 25: 8-13.

GOMES, FB; MORAES, JC; ASSIS, GA. 2008. Silício e imidacloprid na colonização de plantas por Myzuspersicae e no desenvolvimento vegetativo da batata inglesa. Ciência Rural 38: 1209-1213.

GOUSSAIN, MM; MORAES, JC, CARVALHO, J; NOGUEIRA, NL; ROSSI, NL. 2002. Efeito da aplicação de silício em plantas de milho no desenvolvimento biológico da lagartado-cartucho Spodopdera frugiperda (J.E. Smith) (Lepidoptera: Noctuidae). Neotropical Entomology 31: 305-310.

GOZZO, F; FAORO, F. 2013. Systemic Acquired Resistance ( 50 years after discovery): moving from the lab to the field. Journal of Agricultural and Food Chemistry 61: 12473-12491.

KVEDARAS, OL; BYRNE, MJ; COOMBES, NE; KEEPING, MG. 2009. Influence of plant silicon and sugarcane cultivar on mandibular wear in the stalk borer Eldana saccharina. Agricultural and Forest Entomology, 11: 301-306.

LUZ, FJF; SABOYA, RCC; PEREIRA, PRVS. 2002. O cultivo do repolho em Roraima. Circular Técnica 07. Embrapa Roraima.

MA, JF; YAMAJI, N; MITANI-UENO, N. 2011.
Transport of silicon from roots to panicles in plants. In: PROCEEDINGS OF THE JAPAN ACADEMY. Series B Physical and Biology Science 87: 377-385.

MONNERAT, RG; BORDA, D; CASTELO BRANCO, M; FRANÇA, FH. 2000. Efeito de Bacillus thuringiensis Berliner e inseticidas químicos sobre a traça-das-crucíferas, Plutella xylostella $(\mathrm{L}$.$) (Lepidoptera:Yponomeutidae)$ e seus parasitoides. Anais da Sociedade Entomológica do Brasil 29: 723-730.

NAVAS, R; NUNES, JMC; JUNIOR, JBV. 2016. Aplicação de ferro e silício na produção de mudas de eucalipto. Revista Agrarian 9: 137-136.

NERI, DKP; MORAES, JC; GAVINO, MA. 2005. Interação silício com inseticida regulador de crescimento no manejo da lagarta do cartucho Spodoptera frugiperda (J.E. Smith, 1797) (Lepidoptera: Noctuidae) em milho. Ciência e Agrotecnologia 29: 1167-1174.

REYNOLDS, OL; KEEPING, MG; MEYER, JH. 2009. Silicon-augmented resistance of plants to herbivorous insects: a review. Annals of Applied Biology 155: 171-186.

RIBAS, PP; MATSUMURA, ATS. 2009. A química dos agrotóxicos: impactos sobre a saúde e o meio ambiente. Revista Liberato 10: $149-158$.

SANTOS, MC; JUNQUEIRA, AMR; SÁ, VGM; ZANÚNCIO, JC; BAUCH, MA; SERRÃO, JE. 2012. Efeito do silício em aspectos comportamentais e na história de vida de Tuta absoluta (Meyrick) (Lepidoptera: Gelechiidae). Revista Brasileira de Agropecuária Sustentável 2: 76-88.

SOUSA, JV; RODRIGUES, CR; LUZ, JMQ; CARVALHO, PC; RODRIGUES, TM; BRITO, CH. 2010. Silicato de potássio via foliar no milho: fotossíntese, crescimento e produtividade. Bioscience Journal 26: 502-513.

TEODORO, PQ; RIBEIRO, LP; OLIVEIRA, EP; CORRÊA, CCG; TORRES, FE. 2015. Acúmulo de massa seca na soja em resposta a aplicação foliar com silício sob condições de déficit hídrico. Bioscience Journal 31: 161-170.

VILELA, M; MORAES, JC; ALVES, E; SANTOS-CIVINADES, TM; SANTOS, FA. 2014. Induced resistance to Diatraea saccharalis (Lepidoptera: Crambidae) via silicon application in sugarcane. Revista Colombiana de Entomologia 40: 44-48.

VILLAS BOAS, GL; CASTELO BRANCO, M; MEDEIROS, MA; MONNERAT, RG; FRANÇA, FH. 2004. Inseticidas para o controle da traça das crucíferas e impactos sobre a população natural de parasitoides. Horticultura Brasileira 22: 696-699.

ZHUANG, HM; WANG, KF; MIYATA, T; WU, ZJ; XIE, LH. 2011. Identification and expression of caspase-1 gene under heat stress in insecticide-susceptible and -resistant Plutella xylostella (Lepidoptera: Plutellidae). Molecular Biology Reports 38: 2529:2539. 